\title{
A path analysis of five-factor personality traits, self-efficacy, academic locus of control and academic achievement among online students
}

Ekrem Bahçekapılı

Karadeniz Technical University, Turkey

Selçuk Karaman

Atatürk University, Turkey

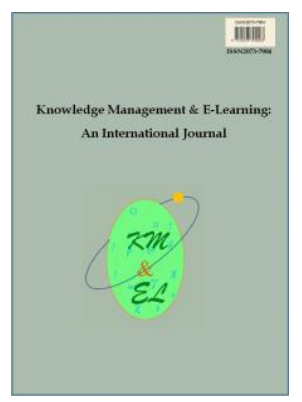

Knowledge Management \& E-Learning: An International Journal (KM\&EL) ISSN 2073-7904

\section{Recommended citation:}

Bahçekapıl1, E., \& Karaman, S. (2020). A path analysis of five-factor personality traits, self-efficacy, academic locus of control and academic achievement among online students. Knowledge Management \& ELearning, 12(2), 191-208. https://doi.org/10.34105/j.kmel.2020.12.010 


\title{
A path analysis of five-factor personality traits, self-efficacy, academic locus of control and academic achievement among online students
}

\author{
Ekrem Bahçekapıl1* \\ Faculty of Economics and Administrative Sciences \\ Karadeniz Technical University, Turkey \\ E-mail: ekrem.bahcekapili@ktu.edu.tr
}

\section{Selçuk Karaman}

Kazım Karabekir Faculty of Education

Atatürk University, Turkey

E-mail: skaraman@atauni.edu.tr

*Corresponding author

\begin{abstract}
This study tests the direct and indirect effects of online learners' personality traits, self-efficacy, and academic locus of control variables on grade point average (GPA) via path analysis. The participants of the study are 525 online learners from two different universities in Turkey. The results of the study reveal a good fit of the proposed model. Relationships in the research model show that self-efficacy has a positive direct effect and external academic locus of control has a negative direct effect on academic achievement. Conscientiousness, openness, and neuroticism have an indirect effect on the GPA, mediated by self-efficacy and external academic locus of control. Results are interpreted with the intent of providing an enhanced understanding of the importance of personality in students' success at online learning experience.
\end{abstract}

Keywords: Online learning; Personality traits; Self-Efficacy; Locus of control; Grade point average

Biographical notes: Ekrem Bahçekapılı is an assistant professor at the Management Information Systems, Faculty of Economics and Administrative Sciences, Karadeniz Technical University. He received $\mathrm{PhD}$ in educational technology. Her research interests are distance education, online learning, the use of technology in the education of the hearing impaired and digital transformation in higher education. Bahçekapılı is also the co-editor of Journal of Information Systems and Management Research.

Selcuk Karaman is a professor at the Computer Education \& Instructional Technology Department, Kazım Karabekir Faculty of Education, Ataturk University in Turkey. He has completed his bachelor's degree in Computer Education and received master and $\mathrm{PhD}$ in quantitative methods. He is director of digital transformation office in Ataturk University. He has research and teaching expertise in educational technology such as e-learning, instructional design, statistics and digital transformation in education. 


\section{Introduction}

Online learning offers many opportunities such as easy access to education, low cost, flexible learning opportunities, standard learning content, and easy access to experts (Kaya, 2002). Considering the effectiveness of online learning, it is stated that the subject is comprehensive (Tzeng, Chiang, \& Li, 2007). In this context, Shachar and Neumann (2003) draw attention to the students' academic achievement, student satisfaction, students' attitudes, and evaluation of teaching. These indicators play an important role in the success and quality of online learning practices. Assessment tools for measuring academic achievements, such as course notes, test scores or general academic average scores, provide a more standard and more objective assessment mechanism, which refers to the same meaning as accepted by educational institutions.

The most important elements of online learning are students and they can affect education processes. Some student related factors affecting online learning processes; dropout (Choi \& Kim, 2018), increased responsibility for learning, poor technical competence, communication and feedback problems are some of these (BartolicZlomislic \& Bates, 1999; Leontyeva, 2018). Besides, considering online learning environments, students' learning responsibilities are higher than face-to-face learning environments (Kiryakova, 2009), and the limitations of the communication and interaction opportunities in online learning environments emphasize the individual characteristics of students (Moore, 1993). Therefore, considering the individual characteristics, interests, needs, and attitudes of the students is important for the effective online learning process (Bhagat, Wu, \& Chang, 2019; Dabbagh, 2007).

The individual characteristics of the students are explained by many variables such as motivation, personality, self-efficacy, self-esteem, self-regulation, anxiety, stress, locus of control, and self-perception. Some individual characteristics frequently change in time. For example, motivation is an important individual characteristic, and many factors can influence and can change it frequently (Viets, Walker, \& Miller, 2002). Some individual characteristics develop and are shaped from childhood to adulthood with a rare change. Keller (2010) refers to this situation:

...human motivation includes the concept of traits in the form of psychological constructs that define specific personality in regard to various aspects of personality such as the need to achieve, perceptions of control, curiosity, attributions for success or failure, and anxiety. Also, a distinction is made between trait versus state conditions in regard to virtually all motivational concepts. A trait is presumed to refer to a stable predisposition to behave in a certain way. In contrast, states refer to the disposition to demonstrate a given motive or personality characteristic at a given point in time or in specific types of situations. (p. 15)

Personality traits are a feature that individuals create throughout their lives and usually show minor change (Harris, Brett, Johnson, \& Deary, 2016). Similarly, selfefficacy (Multon, Brown, \& Lent, 1991; Usher \& Pajares, 2008) and locus of control (Findley \& Cooper, 1983) are also individual characteristics that are shaped throughout the lives of individuals. Knowing how the individual characteristics of students affect academic achievement in online learning environments can contribute to researchers and managers in the field to understand online learners. Therefore, which individual characteristics should be addressed is an important question. It may be helpful if the individual characteristics to be addressed are constant and more consistent. It is possible to make better inferences about the students who will be included in online learning by examining the current individual and academic characteristics of the students. 
The evaluation of some individual characteristics and academic achievement on a theoretical model will contribute to the design and creation of the effective online learning environments. Besides, this model will contribute to the evaluation of the relationship between the individual characteristics and academic achievement, to reveal the direct and indirect effects between the variables and to control the effects of other variables that may impact success at online learning. When we examine the models that predict student achievement in online learning, it is seen that these studies are not based on distance education theories and the academic achievement variable has not been adequately studied (Aydoğdu \& Tanrıkulu, 2013; Freeze, Alshare, Lane, \& Wen, 2010; Hassanzadeh, Kanaani, \& Elahi, 2012; Lin, 2007; Lin \& Chen, 2012; Selim, 2007).

This study aims to develop a model that predicts the academic achievement of the students in online learning by their characteristics such as personality traits, self-efficacy and locus of control (see Fig. 1). This research seeks to address the following questions:

1. What are the direct and indirect effects of the personality traits of students (conscientiousness, extraversion, openness, neuroticism, and agreeableness) on academic achievement?

2. What are the effects of the students' self-efficacy and locus of control (external and internal) features on academic achievement?

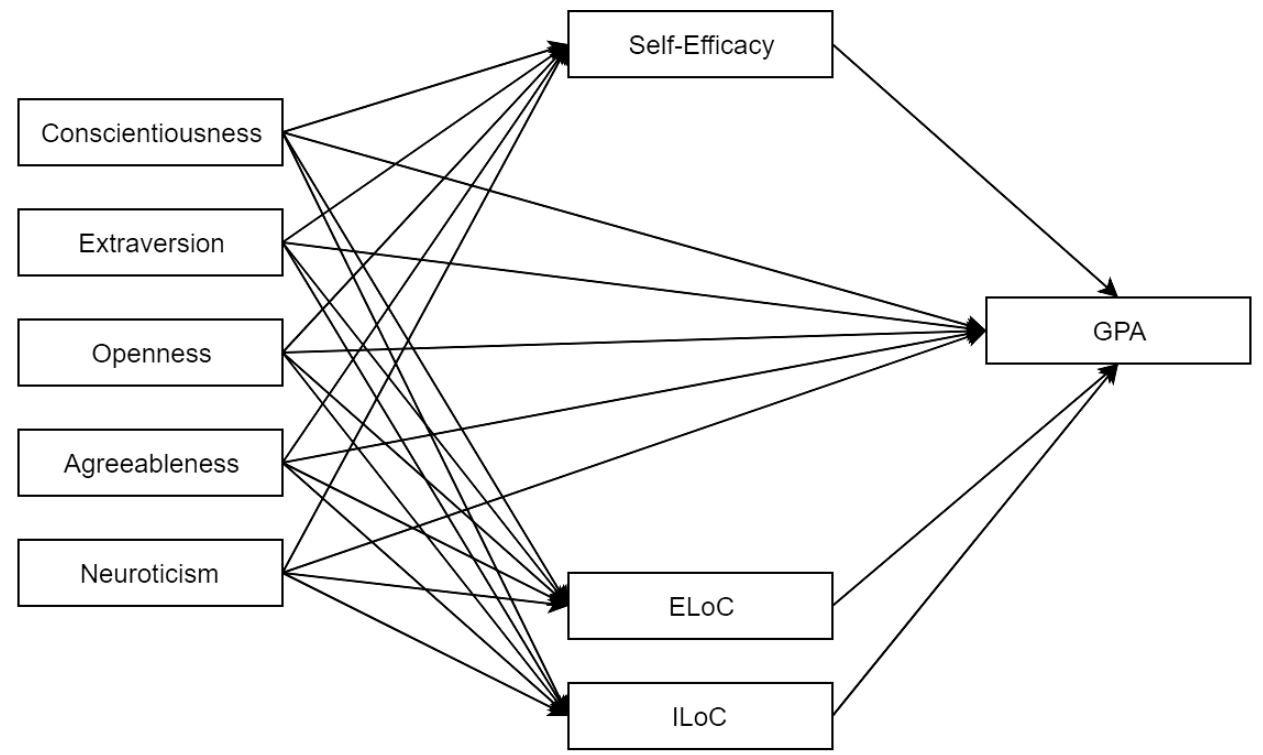

ELoC: External Academic Locus of Control, ILoC: Internal Academic Locus of Control, GPA: Grade Point Average

Fig. 1. Proposed model

\section{Theoretical framework}

\subsection{Personality traits}

"Personality refers to an individual's characteristic patterns of thought, emotion, and behavior, together with the psychological mechanisms - hidden or not-behind those 
patterns" (Funder, 2013, p. 5). There are many theories about personality. Each theory tries to explain the personality from a specific point of view. Burger (2006) mainly divides personality theories into six approaches: Biological approach, Psychoanalytic approach, Humanistic approach, Behavioral/Social Learning approach, Cognitive approach, and Trait approach. One of the important models of the trait approach is the five-factor model of personality. The five-factor model of personality is widely preferred in educational research (Göncz, 2017). Therefore, this study is based on this model. The Five-factor model summarizes personality traits in five broad factors (Gosling \& Mebta, 2013). Factors are as follows: Conscientiousness, Extraversion, Openness, Agreeableness, and Neuroticism (Table 1).

Table 1

Five-factor model of personality

\begin{tabular}{|c|c|}
\hline Trait & Explanation \\
\hline Conscientiousness & $\begin{array}{l}\text { Highly conscientious individuals are orderly, planned, they act } \\
\text { dutifully and take responsibility, and hence, they are patient and } \\
\text { committed to the success *. }\end{array}$ \\
\hline Extraversion & $\begin{array}{l}\text { Highly extraverted individuals are assertive and sociable, often } \\
\text { self-confident, talkative and they love to be in the community and } \\
\text { social environments *. }\end{array}$ \\
\hline Openness & $\begin{array}{l}\text { Individuals with highly open personalities are generally cultured, } \\
\text { generating new and interesting ideas, having creativity, with a high } \\
\text { level of imagination and intellectual curiosity. They are open- } \\
\text { minded and think independently and untraditionally *. }\end{array}$ \\
\hline Agreeableness & $\begin{array}{l}\text { Agreeable individuals are compassionate, respectful, tolerant, } \\
\text { confident, trustworthy preferring cooperation, they easily adapt, } \\
\text { and they are helpful *. }\end{array}$ \\
\hline Neuroticism & $\begin{array}{l}\text { Emotionally unstable individuals are prone to experiencing } \\
\text { negative emotions, such as anxiety, depression, irritation, and } \\
\text { vulnerability in everyday situations and their mood often changes *. }\end{array}$ \\
\hline \multicolumn{2}{|c|}{ Note. * Barrick \& Mount (1991); Burger (2006); John \& Srivastava (1999); Sudak \& Zehir (2013) } \\
\hline \multicolumn{2}{|c|}{$\begin{array}{l}\text { The personality traits and GPA have been studied frequently in face-to-face } \\
\text { learning environments, and many studies have found a positive relationship between } \\
\text { personality traits and GPA (Poropat, 2009; Salgado \& Táuriz, 2014; Trapmann, Hell, } \\
\text { Hirn, \& Schuler, 2007; Vedel, 2014). On the other hand, Bahçekaplla and Karaman (2015) } \\
\text { stated that the studies examining the relationship between the five-factor personality traits } \\
\text { and GPA are limited in online learning (See Table 2). The relationship between } \\
\text { conscientiousness and GPA has sometimes been positive with somewhat insignificant } \\
\text { scores. As to openness, the relationship was generally positive, but one study found a } \\
\text { negative relation. Considering the extraversion, the situation seems complex. While in } \\
\text { one of the studies, relationship between extraversion and GPA was positive, in other two } \\
\text { studies the relationship was found to be negative and in another study the correlation was } \\
\text { found insignificant. For neuroticism and GPA, a negative relationship was observed in } \\
\text { two studies and an insignificant relationship in one study. Finally, in terms of } \\
\text { Agreeableness, two positive and one insignificant relationship have been revealed with } \\
\text { GPA. Though all of these findings are based on several studies, they do not provide a } \\
\text { clear understanding of the relationship between personality traits and GPA. }\end{array}$} \\
\hline
\end{tabular}


Table 2

Relationship between five-factor personality traits and academic achievement in online learning

\begin{tabular}{ll}
\hline Authors (year) & Conclusion \\
\hline $\begin{array}{l}\text { Orvis, Brusso, } \\
\text { Wasserman, \& Fisher, } \\
(2010)\end{array}$ & $\begin{array}{l}\text { The relationship between academic achievement and } \\
\text { Conscientiousness and Openness variables (none), and } \\
\text { Extraversion variable (+) } \\
\text { Kim \& Schniederjans } \\
\text { The relationship between Neuroticism and academic achievement } \\
(-) \text { while the relationship between academic achievement and } \\
\text { other personality traits (+) }\end{array}$ \\
$\begin{array}{l}\text { Schniederjans \& Kim } \\
\text { The relationship between academic achievement and extraversion } \\
\text { (none), Neuroticism (-), other personality traits (+) }\end{array}$ \\
$\begin{array}{l}\text { The relationship between academic achievement and } \\
\text { Extraversion (-), Openness variable (+), other personality traits } \\
\text { (none) }\end{array}$ \\
\hline Note. +: Positive significant relationship, - Negative significant relationship, none: Not a meaningful
\end{tabular}

Note. +: Positive significant relationship, -: Negative significa
relationship. Adapted from Bahçekapılı \& Karaman (2015)

\subsection{Self-efficacy}

Bandura (1994) defined self-efficacy as people's beliefs about their capabilities to produce the designated level of performance that exercises influence over events that affect their lives. Self-efficacy affects people's feelings, thoughts, motivation, and behavior (Bandura, 1993). Besides, individuals' physical and emotional state, his/her personal experiences, the experiences emerging from taking others as a model, and social approval influence on self-efficacy (Bandura, 1977).

Schunk (2009) stated that self-efficacy is closely related to learning and success. Individuals with high self-efficacy are more resistant to the challenges they encounter, and they become more successful (Kurbanoğlu, 2004). Individuals with high self-efficacy struggle more in places where achievement is needed (Schunk, 2009). Studies reveal that there is a relationship between self-efficacy and academic achievement (Pintrich \& de Groot, 1990; Zimmerman, 2009). Further many studies showed that self-efficacy plays an important role in the achievement of students in online learning environments (Ejubović \& Puška, 2019; Ergul, 2004; Joo, Lim, \& Kim, 2013; Wang, Shannon, \& Ross, 2013).

\subsection{Locus of control}

The locus of control is a concept conceptualized by Rotter (1966), signifies the extent to which individuals believe their lives are controlled by themselves (internal locus of control) or by external factors (external locus of control). The studies conducted reveal that the academic achievement of the individuals having a high level of internal locus of control is higher, compared to external locus of control and they become more resistant when they face challenges, and their self-esteem is higher, and they become confident in themselves. Hence, their emotional health becomes better (Yeşilyaprak, 2004).

Given the studies investigating the relationship between locus of control and academic achievement, it is seen that there is no clear understanding of this issue. Some studies reveal a positive relationship between the locus of control and academic 
achievement (Fulton, Ivanitskaya, Bastian, Erofeev, \& Mendez, 2013; Varnhagen \& Wright, 2008), some of them point out a negative relationship (Wang \& Newlin, 2000; Yukselturk \& Bulut, 2007) and another part reveals a non-meaningful relationship (Joo et al., 2013; Levy, 2007).

\section{Methods}

\subsection{Participants}

The participants of the study are 525 students (200 female, 325 male), studying in two different universities in Turkey; their age varies between 19 and $59(\mathrm{M}=30.9)$. The participants in both universities attend a distance education program. The participants attend their classes in a live class environment at a planned time. In the lessons, the instructor teaches the lesson live with the help of a whiteboard, presentation, and other materials in online learning environments. The participants engage vocally in the lesson when required by the instructor, and they may communicate with all participants and the instructor instantly during the lesson by using the chat option. It is possible to access the lesson taught live and access the documents related to these courses. Both universities provided technical support to the participants via telephone and e-mail. The participants take the midterm exams online, but the final exam in a classroom as a proctoring the exam. While the midterm exams have $20 \%$ of the total grade, the final exams possess $80 \%$ of the total grade.

\subsection{Measures and instruments for data collection}

For data collection, three different scales were used. These are namely: the five-factor model of personality scale, the academic locus of control scale and general self-efficacy scale. Below is the explanation of each tool.

In this study, as an indicator of the academic achievement of the students, the Grade Point Average (GPA) used. GPA is a number representing the average value of the accumulated final grades earned in courses at the end of the first semester. GPA value ranges from 0 to 4 . GPA values are obtained from distance learning centers of the universities.

\subsubsection{The five-factor model of personality}

This scale was used to measure the main personality variables in the model. The fivefactor model of personality scale consists of 44 items to measure personality traits. BenetMartínez and John (1998) developed this scale under the name "The Big Five Inventory". The scale comprises five factors named "Neuroticism", "Extraversion", "Openness", "Agreeableness", and "Conscientiousness". There are 8 items in "Neuroticism" and "Extraversion" factors, while 9 items exist in "Agreeableness" and "Conscientiousness" factors and 10 items exist in the "Openness" factor. The scale is presented to the participants using a 5-point Likert-type scale ("1 = I strongly disagree", "2 = I disagree", "3 = Undecided", "4 = I agree" and "5 = I strongly agree").

The scale was adapted to Turkish through an international study in which many different countries from the world participated (Sümer, Lajunen, \& Özkan, 2005). It is reported that the Cronbach alpha reliability values of the subscales were at acceptable 
levels (lowest factor: 0.64 , highest factor: 0.77 ). The validity and reliability of the scale were revealed in a cross-cultural study (Schmitt, Allik, McCrae, \& Benet-Martínez, 2007). In this study, Cronbach's alpha reliability values were calculated as follows: lowest factor: 0.56 , and highest factor: 0.75 .

\subsubsection{Academic locus of control}

The scale was developed by Akin (2007), and it is used to determine the academic locus of control of students. The scale consists of 2 sub-factors namely "External Locus of Control" consisting of 11 items and "Internal Locus of Control" consisting of 6 items. Hence, the scale consists of 17 items in total. The scale is presented to the participants using a 5-point Likert scale "1 = Completely contrary", "2 = Fairly contrary", "3 = Undecided", "4 = Fairly appropriate" and "5 = Completely appropriate". The high scores of participants in both sub-factors indicate that the participant has the traits of the relevant dimension at a very high level. Akın (2007) found that internal consistency, reliability coefficients were 0.94 for the academic internal locus of control and 0.95 for the academic external locus of control, while test-retest reliability coefficients were 0.97 for the academic internal locus of control and 0.93 for the academic external locus of control. In this study, the Cronbach alpha reliability values for the subscales of the scale were calculated as 0.79 for the external locus of control and 0.71 for internal locus of control.

\subsubsection{General self-efficacy}

It is used to assess general self-beliefs of students. The General Self-Efficacy Scale was developed in Germany by Schwarzer and Jerusalem and translated into 28 languages (Schwarzer \& Jerusalem, 1995). The scale uses a 4-point Likert-type scale $(1=$ "Not true", 2 = "Somewhat accurate", 3 = "More accurate" and 4 = "Fully accurate") and consists of 10 items. While the minimum score is 10 , the maximum score is 40 . High scores indicate that the participant's level of self-efficacy is high. It is indicated that the internal consistency of the scale varies between 0.75 and 0.91 in studies conducted in different countries (Scholz, Gutiérrez Doña, Sud, \& Schwarzer, 2002). The scale was translated into Turkish by Yesilay, Schwarzer, and Jerusalem (1997) and the Cronbach's reliability coefficient at the end of the studies conducted in five countries including Turkey was found to be 0.81 (Luszczynska, Gutiérrez-Doña, \& Schwarzer, 2005). In this study, the Cronbach alpha reliability value of the scale was calculated as 0.89 .

\subsection{Procedure}

The data were collected at the end of the semester interval from two universities in Turkey. The participation in the study was voluntarily. Participants' approval was taken before the inclusion. While the data were obtained from one university via printed forms, online forms were used to collect data from the other university. While the study aimed to reach 180 students in this way, 160 students voluntarily took part in the study.

In the other university, where the online forms were used for data collection, firstly, the online form as the data collection tool was logged into the education management system and the students were asked to fill out the forms if they participate in the study. In this process, the aim was to reach 2,000 students; however, approximately 479 students filled the forms. This response rate is acceptable for online data collection tools according to Sax, Gilmartin, and Bryant (2003). 


\subsection{Data analysis}

To validate the hypotheses, the partial least square structural equation modeling technique (PLS-SEM) was utilized as the method of data analysis, using SPSS AMOS 19. Since the PLS approach is more suitable concerning prediction-oriented objective, this approach was employed in the study. (Dijkstra \& Henseler, 2015; Hair Jr, Matthews, Matthews, \& Sarstedt, 2017). Before the analysis, the data obtained from the sample were subjected to the following operations: data cleaning, missing data analysis, testing normality, and determining multicollinearity problems.

\section{Results}

\subsection{Measurement validation}

\subsubsection{Evaluation of normality and linearity}

Skewness and kurtosis values were examined to determine whether the data showed a normal distribution. It was found that the skewness values of each variable ranged from 0.51 to +0.59 while the kurtosis values ranged from -0.55 to -0.03 . This indicates that a normal distribution is achieved. Kline (2011) states that the skewness values between -3 and +3 and the kurtosis values between -10 and +10 can be considered as a normal distribution. Besides, the scatter plot matrix was used to investigate multivariate normality and linearity. Since the scatter plot matrix in the graph shows an elliptical distribution, this is accepted as a sign of multivariate normality and linearity (Çokluk, Şekercioğlu, \& Büyüköztürk, 2014).

\subsubsection{Evaluation of sampling adequacy and multicollinearity problem}

The adequacy of the available data is crucial in testing the model, presented in studies of structural equation modeling. In this study, 525 participants' data were used in the evaluation of the model. While Kline (2011) states that the sample size should be larger than the number of parameters multiplied by 10, Barrett (2007) argues that a sample size below 200 would constitute a problem. Since the number of samples exceeds 200 (n = $525)$, it indicates adequate number of participants can be said to ensure.

Table 3

Correlation coefficients between variables

\begin{tabular}{llllllllll}
\hline & GPA & $\mathrm{E}$ & $\mathrm{C}$ & $\mathrm{A}$ & $\mathrm{O}$ & $\mathrm{N}$ & $\mathrm{SE}$ & ELoC & ILoC \\
\hline $\mathrm{GPA}$ & 1 & & & & & & & \\
$\mathrm{E}$ & .027 & 1 & & & & & & \\
$\mathrm{C}$ & .068 & $.315^{* *}$ & 1 & & & & & \\
$\mathrm{~A}$ & -.013 & $.189^{* *}$ & $.397^{* *}$ & 1 & & & & \\
$\mathrm{O}$ & .070 & $.413^{* *}$ & $.363^{* *}$ & $.276^{* *}$ & 1 & & & \\
$\mathrm{~N}$ & -.072 & $-.275^{* *}$ & $-.401^{* *}$ & $-.409^{* *}$ & $-.257^{* *}$ & 1 & & \\
$\mathrm{SE}$ & $.136^{* *}$ & $.458^{* *}$ & $.392^{* *}$ & $.197^{* *}$ & $.474^{* *}$ & $-.359^{* *}$ & 1 & \\
$\mathrm{ELoC}$ & $-.160^{* *}$ & $-.117^{* *}$ & $-.407^{* *}$ & $-.209^{* *}$ & $-.191^{* *}$ & $.228^{* *}$ & $-.191^{* *}$ & 1 & \\
$\mathrm{ILoC}$ & .033 & .42 & $.286^{* *}$ & $.224^{* *}$ & $.171^{* *}$ & -.075 & $.154^{* *}$ & $.278^{* *}$ & 1 \\
\hline
\end{tabular}

Note. E: Extraversion, C: Conscientiousness, A: Agreeableness, O: Openness, N: Neuroticism, SE: Self-Efficacy, ELoC: External Locus of Control, ILoC: Internal Locus of Control, ${ }^{* *} p<.01$ 
Table 3 shows that the correlation coefficients between the variables are less than 0.9. This indicates that there is no multicollinearity problem among the variables of the study (Çokluk et al., 2014).

\subsection{Testing the main model}

The proposed model was tested using the Maximum-Likelihood method in AMOS 19. The prerequisite for using the maximum likelihood approach is multivariate normality (Kline, 2011, p.154) and multivariate normal distribution was confirmed. According to Henseler, Hubona, and Ray (2016), "PLS path models can and should be assessed globally through tests of model fit and approximate measures of model fit". At the end of the test, the goodness of fit indexes is presented in Table 4.

Table 4

Goodness of fit indexes related to the intended model

\begin{tabular}{lll}
\hline Model Conformity Index & Value & Evaluation Criteria * \\
\hline$X^{2}$ & $p=0.312$ & Should be $p>0.05$ \\
$X^{2} / d f$ & $(2.329 / 2) 1.164$ & Should be $<3$ \\
SRMR & 0.0078 & $<0.05$ an indicator of good fit \\
RMSEA & 0.018 & $<0.05$ an indicator of good fit \\
CFI & 1.000 & $>=0.90$ an indicator of good fit \\
RMR & 0.003 & $<=0.10$ an indicator of good fit \\
GFI & 0.999 & $>=0.90$ an indicator of good fit \\
\hline
\end{tabular}

Note. * Evaluation criteria are determined according to Barrett (2007); Schreiber, Nora, Stage,

Barlow, \& King (2006); Kline (2011); Schumacker \& Lomax (2010); Bryne (1994)

If the goodness of fit indexes related to the Intended Model shown in Table 4, it is possible to state that the intended model conforms well.

\subsection{Testing the hypotheses revealed in the model}

After revealing the goodness of fit, the hypotheses are tested in the model as the first research question. Firstly, the direct and indirect effects on the model are presented (Fig. 2 ). Then, the hypotheses are tested according to the significance level of these effects. The direct, indirect and total effects of the variables in the model are presented in Table 5.

In the light of the data presented in Table 5, the variables included in the model explain the $4.4 \%$ of the variance on GPA scores of students. The GPA is influenced at most by the ELoC with an effect size of $\beta=-0.156$, and respectively by self-efficacy with an effect size of $\beta=0.13$. At the same time, these two variables directly affect the GPA score. On the other hand, personality traits of conscientiousness, openness, and neuroticism indirectly affect the GPA. While the self-efficacy variable takes a mediating role for conscientiousness $(\beta=0.022)$, openness $(\beta=0.037)$ and neuroticism $(\beta=-0.023)$ variables to affect indirectly the GPA, the ELoC of control variable has a similar mediating role for conscientiousness $(\beta=0.056)$ and neuroticism $(\beta=-0.011)$ in this sense. Extraversion and agreeableness variables and internal locus of control variables have no significant effect on GPA. 


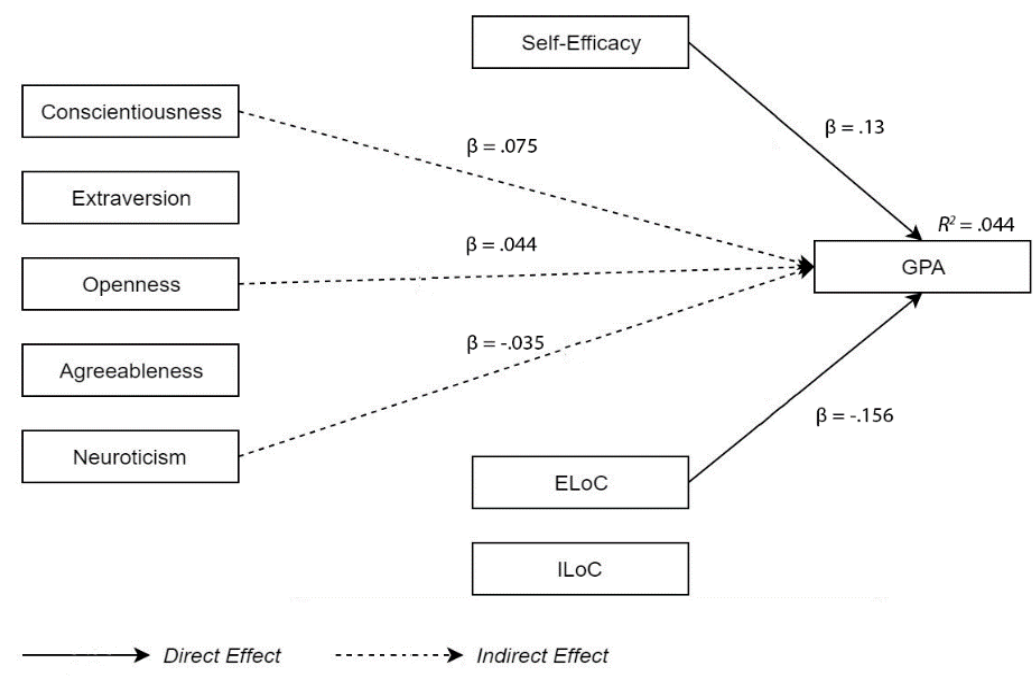

ELOC: External Academic Locus of Control, ILoC: Internal Academic Locus of Control, GPA: Grade Point Average

Fig. 2. Summary of significant standardized direct and indirect effects

Table 5

Indirect and direct standardized effects between the variables

\begin{tabular}{|c|c|c|c|}
\hline \multirow{2}{*}{ Predicted Variable } & \multirow{2}{*}{ Predictor Variable } & \multicolumn{2}{|c|}{ Standardized Effects } \\
\hline & & Direct & Indirect \\
\hline \multirow[t]{8}{*}{ GPA $\left(R^{2}=0.044\right)$} & $\mathrm{C}$ & -0.022 & $\begin{array}{l}0.075^{*} \text { (SE: } 0.022^{*}, \text { ELoC: } \\
\left.0.056^{*} \text {, ILoC: }-0.003\right)\end{array}$ \\
\hline & $\mathrm{E}$ & -0.047 & 0.027 \\
\hline & $\mathrm{O}$ & 0.019 & $\begin{array}{l}\text { 0.044*(SE: } 0.037 * \text { ELoC: } \\
0.008, \text { ILoC: }-0.001)\end{array}$ \\
\hline & $\mathrm{N}$ & -0.037 & $\begin{array}{l}-0.035^{*} \text { (SE: }-0.023^{*}, \text { ELoC: } \\
\left.-0.011^{*}, \text { ILoC: }-0.001\right)\end{array}$ \\
\hline & $\mathrm{A}$ & -0.071 & -0.006 \\
\hline & SE & $0.13 *$ & - \\
\hline & ELoC & $-0.156 *$ & - \\
\hline & ILoC & -0.013 & - \\
\hline \multirow[t]{5}{*}{$\mathrm{SE}\left(R^{2}=0.365\right)$} & $\mathrm{C}$ & $0.166 *$ & - \\
\hline & $\mathrm{E}$ & $0.252 *$ & - \\
\hline & $\mathrm{O}$ & $0.283 *$ & - \\
\hline & $\mathrm{N}$ & $-0.179 *$ & - \\
\hline & A & -0.068 & - \\
\hline \multirow[t]{5}{*}{$\operatorname{ELoC}\left(R^{2}=0.174\right)$} & $\mathrm{C}$ & $-0.362 *$ & - \\
\hline & $\mathrm{E}$ & 0.043 & - \\
\hline & $\mathrm{O}$ & -0.052 & - \\
\hline & $\mathrm{N}$ & 0.069 & - \\
\hline & A & -0.031 & - \\
\hline \multirow[t]{5}{*}{$\operatorname{ILoC}\left(R^{2}=0.112\right)$} & $\mathrm{C}$ & $0.254 *$ & - \\
\hline & $\mathrm{E}$ & -0.08 & - \\
\hline & $\mathrm{O}$ & 0.093 & - \\
\hline & $\mathrm{N}$ & 0.09 & - \\
\hline & $\mathrm{A}$ & $0.15 *$ & - \\
\hline
\end{tabular}




\section{Discussion}

In this section, research results are discussed as two parts in terms of variables (selfefficacy, academic control focus and five-factor personality traits) with and without significant effect on academic achievement.

\subsection{Variables that have a significant effect on academic achievement}

According to the results, when self-efficacy increases, so does the academic achievement of students. The general self-efficacy is a way of thinking individual shapes at the end of experiences during his/her life. Individuals with a high general self-efficacy perception have higher beliefs in their ability to complete a task successfully (Bandura, 1994). Literature reveals that self-efficacy is a prominent variable related to the motivation and performance of students in online learning environments (Lee, 2015). The belief that an individual can execute a job may positively affect academic achievement in online learning environments that require different qualifications and traits. The responsibility of the education for students in online learning environments is more intense in comparison with face-to-face education environments. Besides, as mentioned in some studies (Moos \& Azevedo, 2009; Wang et al., 2013), the belief to use efficiently the technology would be a factor affecting positively the achievement in environments, where the technology is largely used. Hence, the studies conducted on this topic in online learning (Joo et al., 2013; Wang \& Newlin, 2002) are consistent with this study.

Research findings reveal that when the score of the external academic locus of control increases, there will be a decline in the academic achievement of the individuals. Individual with a high external academic locus of control attributes their achievement to luck or any external factors other than themselves (Yeşilyaprak, 2004). Hence, when individuals' external academic locus of control increases, the individual passes the responsibility on other factors. The individual links the failure with the teacher, system or teaching method, rather than accepting their responsibility. In this respect, the relationship between external locus of control and success in the research was frequently emphasized in formal education (Buluş, 2011; Cassidy, 2012) and online learning (Wang \& Newlin, 2000; Yukselturk \& Bulut, 2007).

In this study, it was found conscientiousness and openness have a positive and indirect relationship with achievement. However, neuroticism has a negative indirect effect on academic achievement. Online learning requires more learning responsibility for students (Bartolic-Zlomislic \& Bates, 1999). Also, online learning constitutes a new and different learning experience for individuals, who were educated largely with face-toface education throughout their lives. When these qualities of online learning environments are taken into consideration, it could be expected that individuals who are orderly, planned, responsible, decisive, open to new and different ideas should be academically more successful. Besides, it can be expected that the individuals, who tend to be anxious and stressed in face of daily events, would be academically less successful since online learning environments are different and unfamiliar in comparison with faceto-face learning environments.

It was observed that while general self-efficacy and external academic locus of control variables are mediating the conscientiousness and neuroticism variables; only general self-efficacy is mediating the openness personality trait. it should be noted that these results reveal that the personality traits affect the academic achievement indirectly and this effect is achieved through self-efficacy and external locus of control. While the general self-efficacy has a positive direct effect on academic achievement, 
conscientiousness and openness have positive and neuroticism has negative indirect effects on academic achievement through the variable of self-efficacy.

The findings of this research reveal that being planned and orderly, open to independent thinking and to new ideas will increase academic success together with the perception of the individual to succeed a task. Thus, these findings differ from the studies which expressed the effects of personality traits on academic achievement directly, rather than indirectly (Maki \& Maki, 2003; Schniederjans \& Kim, 2005). This results in the belief that personality traits may influence academic achievement through some mediating individual traits. A similar study conducted by Tabak, Nguyen, Basuray, and Darrow (2009) shows that conscientiousness personality trait affects achievement through self-efficacy variables. The studies in online learning examine the effect of the personality traits on academic achievement by using correlation or regression analysis techniques (Maki \& Maki, 2003; Orvis et al., 2010; Schniederjans \& Kim, 2005). A similar study conducted by Tabak et al. (2009) shows that conscientiousness personality trait affects achievement through self-efficacy variables. Therefore, this study can identify this indirect effect.

\subsection{Variables that have an insignificant effect on academic achievement}

According to the results of the study, some of the personality traits are not related to academic achievement on the model. These are extraversion and agreeableness as well as the internal academic locus of control. Individuals with a high level of extraversion are usually defined as sociable, outgoing, talkative and active individuals (Barrick \& Mount, 1993). One can consider these traits as factors. These traits can be considered as factors which may increase academic achievement in online learning environment. Hence, Moore (1993) emphasizes the interaction in online learning environments. This personality trait reserves elements that may increase the student's interaction in the online learning environment. However, in this study, no meaningful effect has been found in this direction. The results of the studies that investigate the effect of extraversion personality trait on the academic achievement vary, while there are studies that showed positive (Orvis et al., 2010), negative (Maki \& Maki, 2003) and insignificant effects (Schniederjans \& Kim, 2005).

The results are similar to those of Schniederjans and Kim's study (2005). The results might have been influenced because the students included in the sample encounter an unfamiliar environment during online learning. Hence, in a study that reveals a positive relationship between the trait extraversion and academic achievement, Orvis et al. (2010) obtained data from face-to-face students receiving also an online course. Students do not receive all their courses through online learning. In this respect, the study of Orvis et al. (2010) leads to some dissimilar results. This may show that if the students know each other and the instructor face to face, there may be more effective interaction than a fully online course.

Schniederjans and Kim (2005) worked only with fully online students and they found that trait extraversion does not have a significant effect on academic achievement consistent with the results. Thus, it would be possible to assert that the characteristics related to the extraversion do not dramatically affect academic achievement for the students studying in online learning environments. Reversely, it would be possible to observe this in students receiving face-to-face education and following parts of their education or some courses on online learning. 
Another personality trait that has no significant effect on academic achievement in the study is agreeableness. The individuals having a high agreeableness personality trait are compassionate, helpful, and reliable, and they also prefer cooperation instead of competition (Burger, 2006). Some elements of this personality trait, such as preferring cooperation instead of competition, may influence academic achievement. Schniederjans and Kim (2005) showed that this personality trait is related positively to academic achievement. Maki and Maki (2003) point out that there is no significant relationship between academic achievement and agreeableness, in parallel with the findings of this study. However, most of the studies that examine the effect of agreeableness personality trait on academic achievement reveal the existence of a positive relationship between personality traits and academic achievement (Bidjerano \& Dai, 2007; Vedel, Thomsen, \& Larsen, 2015). Since the social interaction level of the online programs is low in this study, it is possible to conclude that the agreeableness personality trait is not distinguished in environments where social interaction is at a low level.

The last variable having no influence on academic achievement was found as the internal locus of control. Joo et al. (2013) pointed out that the internal locus of control does not have a significant influence on academic achievement in the study, which was conducted on 897 online learners to examine the effect of internal locus of control on academic achievement. In the literature, it has been observed that the external locus of the control variable is examined instead of the internal locus of control (Wang \& Newlin, 2000; Yukselturk \& Bulut, 2007). This study revealed that the external locus of control has a significant effect on academic achievement unlike the internal locus of control. Hence, the study ascertains that the external locus of control rather than the internal locus of control would contribute better for predicting the academic achievement of online learners.

\section{Conclusions and implications}

The personality traits, which have significant effects on GPA on the main model, have been identified as the conscientiousness, openness and neuroticism personality traits and general self-efficacy and external locus of control. While the effects of the general selfefficacy and external academic locus of control directly affect academic achievement, conscientiousness, openness, and personality traits have an indirect effect on academic achievement. On the other hand, it was revealed that the variables extraversion, agreeableness and internal academic locus of control do not affect academic achievement.

Based on the positive and negative effects of personality traits on academic achievement, student supports should focus on students themselves. Thus, it is necessary to get more information about their psychological traits when students are registered for online learning and act accordingly in the services provided and treat them more sensitively if needed. It is impossible to change the personality traits of students but Some personality behaviors may be facilitated which have a relation with success by designing appropriate learning and support activities. For example, since the external locus of control has a negative effect on academic achievement, it is necessary to provide students who seek to study in online learning environments with precise information about their responsibilities and how the system functions. Also, it is essential to explain all the technological and educational criteria expected from them and ensure that the registered students fulfill these criteria. As for the positive effect of conscientiousness on academic achievement, it is recommended to provide students the course objectives, detailed learning tasks, and course schedule to help them to be more planned and orderly. 
Beyond providing information, the structure of learning tasks can also support students' tendency of some behaviors related to traits. For example, since self-efficacy has a positive effect neuroticism has an adverse effect on academic achievement, the learning tasks to be assigned in online learning should reinforce students' belief that they can accomplish them.

\section{Limitations}

Since the number of questions in the survey tool used in the research was exhaustive and most of the data was obtained through an online form, it may affect the responses given to the survey tool. The data obtained in the study are limited by online learners studying in the academic year 2014-2015 at two different universities in Turkey. The results of the study should be evaluated by considering the distance education systems of the universities.

\section{Acknowledgements}

This study is a part of the first author's doctoral dissertation conducted under the supervision of the second author and also was presented oral report in 3rd International Eurasian Educational Research Congress at the 31 May-3 June 2016.

\section{ORCID}

Ekrem Bahçekapılı (iD https://orcid.org/0000-0002-7538-1712

Selçuk Karaman (iD https://orcid.org/0000-0002-0493-3444

\section{References}

Akın, A. (2007). Akademik kontrol odağı ölçeği: Geçerlik ve güvenirlik çalışması. Çukurova Üniversitesi Eğitim Fakültesi Dergisi, 34(3), 9-17.

Aydoğdu, Y. T., \& Tanrikulu, Z. T. (2013). Corporate e-learning success model development by using data mining methodologies. Ë̆itim ve Bilim, 38(17), 95-111.

Bahçekapıll, E., \& Karaman, S. (2015). Uzaktan eğitimde kişilik özellikleri ve akademik başarı: Bir literatür incelemesi. Ögretim Teknolojileri \& Öğretmen Ĕgitimi Dergisi, 4(3), 26-34.

Bandura, A. (1977). Self-efficacy: Toward a unifying theory of behavioral change. Psychological Review, 84(2), 191-215. doi: 10.1037/0033-295X.84.2.191

Bandura, A. (1993). Perceived self-efficacy in cognitive development and functioning. Educational Psychologist, 28(2), 117-148.

Bandura, A. (1994). Self-efficacy. In V. S. Ramachaudran (Ed.), Encyclopedia of Human Behavior (Vol. 4, pp. 71-81). New York, NY: Academic Press. (Reprinted in H. Friedman [Ed.], Encyclopedia of mental health. San Diego: Academic Press, 1998).

Barrett, P. (2007). Structural equation modelling: Adjudging model fit. Personality and Individual Differences, 42(5), 815-824.

Barrick, M. R., \& Mount, M. K. (1991). The big five personality dimensions and job performance: A meta-analysis. Personnel Psychology, 44(1), 1-26.

Barrick, M. R., \& Mount, M. K. (1993). Autonomy as a moderator of the relationships between the big five personality dimensions and job performance. Journal of Applied 
Psychology, 78(1), 111-118.

Bartolic-Zlomislic, S., \& Bates, A. W. (1999). Investing in on-line learning: Potential benefits and limitations. Canadian Journal of Communication, 24(3): 4.

Benet-Martínez, V., \& John, O. P. (1998). Los Cinco Grandes across cultures and ethnic groups: Multitrait-multimethod analyses of the big five in Spanish and English. Journal of Personality and Social Psychology, 75(3), 729-750.

Bhagat, K. K., Wu, L. Y., \& Chang, C. Y. (2019). The impact of personality on students' perceptions towards online learning. Australasian Journal of Educational Technology, 35(4), 98-108. doi: 10.14742/ajet.4162

Bidjerano, T., \& Dai, D. Y. (2007). The relationship between the big-five model of personality and self-regulated learning strategies. Learning and Individual Differences, 17(1), 69-81. doi: 10.1016/j.lindif.2007.02.001

Bryne, B. M. (1994). Structural equation modeling with EQS and EQS/Windows: Basic concepts, applications, and programming (1st ed.). Mahwah, NJ: Lawrance Erlbaum Associates, Inc.

Buluş, M. T. (2011). Öğretmen adaylarında bireysel farklılıklar perspektifinden amaç yönelimleri, denetim odağı ve akademik başarı. Kuram ve Uygulamada Eğitim Bilimleri, 11(2), 529-546.

Burger, J. M. (2006). Kişilik (İ. D. E. Sarıoğlu, Trans.). İstanbul: Kaknüs Yayınları.

Cassidy, S. (2012). Exploring individual differences as determining factors in student academic achievement in higher education. Studies in Higher Education, 37(7), 793810. doi: 10.1080/03075079.2010.545948

Choi, H. J., \& Kim, B. U. (2018). Factors affecting adult student dropout rates in the Korean Cyber-University degree programs. The Journal of Continuing Higher Education, 66(1), 1-12.

Çokluk, Ö., Şekercioğlu, G., \& Büyüköztürk, Ş. (2014). Sosyal bilimler için cok değişkenli istatistik SPSS ve LISREL uygulamaları (3rd ed.). Ankara: Pegem A Yayincilık.

Dabbagh, N. (2007). The online learner: Characteristics and pedagogical implications. Contemporary Issues in Technology and Teacher Education, 7(3), 217-226.

Dijkstra, T. K., \& Henseler, J. (2015). Consistent partial least squares path modeling. MIS Quarterly, 39(2), 297-316.

Ejubović, A., \& Puška, A. (2019). Impact of self-regulated learning on academic performance and satisfaction of students in the online environment. Knowledge Management \& E-Learning, 11(3), 345-363.

Ergul, H. (2004). Relationship between student characteristics and academic achievement in distance education and application on students of Anadolu University. Turkish Online Journal of Distance Education, 5(2), 81-90.

Findley, M. J., \& Cooper, H. M. (1983). Locus of control and academic achievement: A literature review. Journal of Personality and Social Psychology,44(2), 419-427. doi: 10.1037/0022-3514.44.2.419

Freeze, R. D., Alshare, K. A., Lane, P. L., \& Wen, H. J. (2010). IS success model in elearning context based on students' perceptions. Journal of Information Systems Education, 21(2), 173-184.

Fulton, L. V., Ivanitskaya, L. V., Bastian, N. D., Erofeev, D. A., \& Mendez, F. A. (2013). Frequent deadlines: Evaluating the effect of learner control on healthcare executives' performance in online learning. Learning and Instruction, 23, 24-32.

Funder, D. C. (2013). The personality puzzle (6th ed.). New York, NY: Norton.

Göncz, L. (2017). Teacher personality: A review of psychological research and guidelines for a more comprehensive theory in educational psychology. Open Review of Educational Research, 4(1), 75-95. 
Gosling, S. D., \& Mebta, P. H. (2013). Personalities in a comparative perspective: What do human psychologists glean from animal personality studies. In C. Carere, \& D. Maestripieri (Eds.), Animal Personalities: Behavior, Physiology, and Evolution (p. 129). Chicago and London: University of Chicago Press.

Hair Jr, J. F., Matthews, L. M., Matthews, R. L., \& Sarstedt, M. (2017). PLS-SEM or CB-SEM: updated guidelines on which method to use. International Journal of Multivariate Data Analysis, 1(2), 107-123. doi: 10.1504/ijmda.2017.10008574

Harris, M. A., Brett, C. E., Johnson, W., \& Deary, I. J. (2016). Personality stability from age 14 to age 77 years. Psychology and Aging, 31(8), 862-874.

Hassanzadeh, A., Kanaani, F., \& Elahi, S. (2012). A model for measuring e-learning systems success in universities. Expert systems with Applications, 39(12), 1095910966.

Henseler, J., Hubona, G., \& Ray, P. A. (2016). Using PLS path modeling in new technology research: Updated guidelines. Industrial Management \& Data Systems, $116(1), 2-20$.

John, O. P., \& Srivastava, S. (1999). The big five trait taxonomy: History, measurement, and theoretical perspectives. In L. A. Pervin \& O. P. John (Eds.), Handbook of Personality: Theory and Research (2nd ed., pp. 102-138). New York: Guilford Press.

Joo, Y. J., Lim, K. Y., \& Kim, J. (2013). Locus of control, self-efficacy, and task value as predictors of learning outcome in an online university context. Computers \& Education, 62, 149-158.

Kaya, Z. (2002) Uzaktan Eğitim. Ankara: Pegem A Yayıncılık.

Keller, J. M. (2010). Motivational design for learning and performance: The ARCS model approach (p. 15). New York, NY: Springer.

Kim, E. B., \& Schniederjans, M. J. (2004). The role of personality in web-based distance education courses. Communications of the ACM, 47(3), 95-98.

Kiryakova, G. (2009). Review of distance education. Trakia Journal of Sciences, 7(3), 29-34.

Kline, R. B. (2011). Principles and practice of structural equation modeling (3rd ed.). New York, NY: The Guilford Press.

Kurbanoğlu, S. S. (2004). Öz-yeterlik inancı ve bilgi profesyonelleri için önemi. Bilgi Dünyasl, 5(2), 137-152.

Lee, C.-Y. (2015). Changes in self-efficacy and task value in online learning. Distance Education, 36(1), 59-79. doi: 10.1080/01587919.2015.1019967

Leontyeva, I. A. (2018). Modern distance learning technologies in higher education: Introduction problems. Eurasia Journal of Mathematics, Science and Technology Education, 14(10): em1578.

Levy, Y. (2007). Comparing dropouts and persistence in e-learning courses. Computers \& Education, 48(2), 185-204.

Lin, H. F. (2007). Measuring online learning systems success: Applying the updated DeLone and McLean model. Cyberpsychology \& Behavior, 10(6), 817-820. doi: 10.1089/cpb.2007.9948

Lin, T.-C., \& Chen, C.-J. (2012). Validating the satisfaction and continuance intention of e-learning systems: Combining TAM and IS success models. International Journal of Distance Education Technologies (IJDET), 10(1), 44-54.

Luszczynska, A., Gutiérrez-Doña, B., \& Schwarzer, R. (2005). General self-efficacy in various domains of human functioning: Evidence from five countries. International Journal of Psychology, 40(2), 80-89.

Maki, R. H., \& Maki, W. S. (2003). Prediction of learning and satisfaction in web-based and lecture courses. Journal of Educational Computing Research, 28(3), 197-219.

Moore, M. G. (1993). Theory of transactional distance. In D. Keegan (Ed.), Theoretical Principles Distance Education (pp. 22-38) New York, NY: Routledge. 
Moos, D. C., \& Azevedo, R. (2009). Learning with computer-based learning environments: A literature review of computer self-efficacy. Review of Educational Research, 79(2), 576-600. doi: 10.3102/0034654308326083

Multon, K. D., Brown, S. D., \& Lent, R. W. (1991). Relation of self-efficacy beliefs to academic outcomes: A meta-analytic investigation. Journal of Counseling Psychology, 38(1), 30-38.

Orvis, K. A., Brusso, R. C., Wasserman, M. E., \& Fisher, S. L. (2010). E-nabled for elearning? The moderating role of personality in determining the optimal degree of learner control in an e-learning environment. Human Performance, 24(1), 60-78.

Pintrich, P. R., \& de Groot, E. V. (1990). Motivational and self-regulated learning components of classroom academic performance. Journal of Educational Psychology, 82(1), 33-40. doi: 10.1037/0022-0663.82.1.33

Poropat, A. E. (2009). A meta-analysis of the five-factor model of personality and academic performance. Psychological Bulletin, 135(2), 322-338.

Rotter, J. B. (1966). Generalized expectancies for internal versus external control of reinforcement. Psychological Monographs: General and Applied, 80(1), 1-28.

Salgado, J. F., \& Táuriz, G. (2014). The five-factor model, forced-choice personality inventories and performance: A comprehensive meta-analysis of academic and occupational validity studies. European Journal of Work and Organizational Psychology, 23(1), 3-30.

Sax, L. J., Gilmartin, S. K., \& Bryant, A. N. (2003). Assessing response rates and nonresponse bias in web and paper surveys. Research in Higher Education, 44(4), 409-432.

Schmitt, D. P., Allik, J., McCrae, R. R., \& Benet-Martínez, V. (2007). The geographic distribution of big five personality traits patterns and profiles of human selfdescription across 56 nations. Journal of Cross-Cultural Psychology, 38(2), 173-212.

Schniederjans, M. J., \& Kim, E. B. (2005). Relationship of student undergraduate achievement and personality characteristics in a total web-based environment: An empirical study. Decision Sciences Journal of Innovative Education, 3(2), 205-221.

Scholz, U., Doña, B. G., Sud, S., \& Schwarzer, R. (2002). Is general self-efficacy a universal construct? Psychometric findings from 25 countries. European Journal of Psychological Assessment, 18(3), 242-251.

Schreiber, J. B., Nora, A., Stage, F. K., Barlow, E. A., \& King, J. (2006). Reporting structural equation modeling and confirmatory factor analysis results: A review. The Journal of Educational Research, 99(6), 323-338.

Schumacker, R. E., \& Lomax, R. G. (2010). A beginner's guide to structural equation modeling (3rd ed.). New York, NY: Routledge.

Schunk, D. H. (2009). Eğitimsel bir bakışla öğrenme teorileri (Muzaffer Şahin, Trans. Ed.). Ankara: Nobel Yayın Dağıtım.

Schwarzer, R., \& Jerusalem, M. (1995). Generalized self-efficacy scale. In J. Weinman, S. Wright, \& M. Johnston (Eds.), Measures in Health Psychology: A User's Portfolio. Causal and Control Beliefs (pp. 35-37). Windsor, UK: NFER-NELSON.

Selim, H. M. (2007). Critical success factors for e-learning acceptance: Confirmatory factor models. Computers \& Education, 49(2), 396-413.

Shachar, M., \& Neumann, Y. (2003). Differences between traditional and distance education academic performances: A meta-analytic approach. The International Review of Research in Open and Distributed Learning, 4(2): 9.

Sudak, M. K., \& Zehir, C. (2013). Kişilik tipleri, duygusal zeka, iş tatmini ilişkisi üzerine yapılan bir araştırma. Yönetim Bilimleri Dergisi, 11(22), 141-165.

Sümer, N., Lajunen, T., \& Özkan, T. (2005). Big five personality traits as the distal predictors of road accident involvement. In G. Underwood (Ed.), Traffic and 
Transport Psychology (pp. 215-227). Elsevier.

Tabak, F., Nguyen, N., Basuray, T., \& Darrow, W. (2009). Exploring the impact of personality on performance: How time-on-task moderates the mediation by selfefficacy. Personality and Individual Differences, 47(8), 823-828. doi: 10.1016/j.paid.2009.06.027

Trapmann, S., Hell, B., Hirn, J.-O. W., \& Schuler, H. (2007). Meta-analysis of the relationship between the big five and academic success at university. Zeitschrift für Psychologie/Journal of Psychology, 215(2), 132-151.

Tzeng, G.-H., Chiang, C.-H., \& Li, C.-W. (2007). Evaluating intertwined effects in elearning programs: A novel hybrid MCDM model based on factor analysis and Dematel. Expert Systems with Applications, 32(4), 1028-1044.

Usher, E. L., \& Pajares, F. (2008). Sources of self-efficacy in school: Critical review of the literature and future directions. Review of Educational Research,78(4), 751-796.

Varnhagen, C. K., \& Wright, D. L. (2008). Learning characteristics of veterinary technology students in a distance-education and an on-campus program. Journal of Veterinary Medical Education, 35(3), 449-455.

Vedel, A. (2014). The big five and tertiary academic performance: A systematic review and meta-analysis. Personality and Individual Differences, 71, 66-76.

Vedel, A., Thomsen, D. K., \& Larsen, L. (2015). Personality, academic majors and performance: Revealing complex patterns. Personality and Individual Differences, 85, 69-76. doi: 10.1016/j.paid.2015.04.030

Viets, V. L., Walker, D. D., \& Miller, W. R. (2002). What is motivation to change? A scientific analysis. In M. McMurran (Ed.), Motivating Offenders to Change: A Guide to Enhancing Engagement in Therapy (pp. 15-30). New York, NY: John Wiley \& Sons.

Wang, A. Y., \& Newlin, M. H. (2000). Characteristics of students who enroll and succeed in psychology Web-based classes. Journal of Educational Psychology, 92(1), 137-143.

Wang, A. Y., \& Newlin, M. H. (2002). Predictors of web-student performance: The role of self-efficacy and reasons for taking an on-line class. Computers in Human Behavior, 18(2), 151-163. doi: 10.1016/S0747-5632(01)00042-5

Wang, C.-H., Shannon, D. M., \& Ross, M. E. (2013). Students' characteristics, selfregulated learning, technology self-efficacy, and course outcomes in online learning. Distance Education, 34(3), 302-323. doi: 10.1080/01587919.2013.835779

Yesilay, A., Schwarzer, R., \& Jerusalem, M. (1997). Turkish adaptation of the general self-efficacy scale: Genelleştirilmiş özyeti beklentisi. Retrieved from http://userpage.fu-berlin.de/ health/turk.htm

Yeşilyaprak, B., (2004). Denetim odağı. Yıldız Kuzgun. ve Deniz Deryakulu (Ed.) Eğitimde Bireysel Farklılıklar içinde. Ankara: Nobel Yayın Dağıtım.

Yukselturk, E., \& Bulut, S. (2007). Predictors for student success in an online course. Educational Technology \& Society, 10(2), 71-83.

Zimmerman, B. J. (2009). Self-efficacy and educational development. In A. Bandura (Ed.), Self-Efficacy in Changing Societies (pp. 202-231). Cambridge University Press. 